houses have latrines of any kind. The remedy is very simple and easy of application. No great engineering works are necessary, and the method of prevention can be demonstrated to the most ignorant. There is no community in this country which does not have sufficient resources to carry out the safe disposal of body discharges, and when that is done, typhoid, dysentery, hookworm and a host of other diseases will disappear.

The meagre evidence here presented shows that the loss caused by only a few of the intestinal diseases will total to more than a billion dollars per year. Efficiency is the watchword of the day. The struggle for existence after the war will probably be greater than ever. Shall we enter the contest with this handicap, or shall we strike it from us?

\title{
NATIONAL EFFECTIVENESS AND HEALTH INSURANCE
}

\author{
By John B. Andrews, Ph.D.
}

Secretary, American Association for Labor Legislation.

"When the workers return from the trenches they will not be satisfied with flowers or brass bands." This sentiment, recently expressed by one of our loyal and most influential leaders of organized labor, may be welcomed as a "healthy indication" or opposed as a "seething menace," according to one's point of view. It conforms rather conservatively to the reported pronouncement of Mr. Schwab that "within two years the workers will be running this country." Mr. Schwab for this declaration was publicly denounced as a threatening Bolshevik, but presently he was placed in charge of the nation's shipbuilding, the most urgent and critical job in our war preparations. Politically the sentiment is in harmony with the expression of the official historian of the British army in France, who recently said: "I predict that our next Parliament will be a labor Parliament." And it is most effectively and eloquently reënforced in a recent letter by President Wilson who declares:

Every man with any vision must see that the real test of justice and right action is presently to come as it never came before. The men in the trenches, who have been freed from the economic serfdom to which some of them have been accustomed, will, it is likely, return to their homes with a new view and a new im- 
patience of all mere political phrases, and will demand real thinking and sincere action.

The foregoing sentiment may therefore be regarded as the wellconsidered political expression of some of the keenest and most practical of our forward-looking representative men who are earnestly seeking national effectiveness in a period of supreme national responsibility.

\section{The Public Health Problem}

What national problems are of such supreme importance as to challenge our chief attention in this reconstruction period?

Aside from measures for the development and protection of labor organizations in their campaign for higher wages, shorter hours, and increased control of industry, it is probable that no single factor in industrial betterment will be so widely accepted as vital to the welfare of the masses of the people in this country as the assurance of reasonably healthful working and living conditions. Certainly no other problem of equal importance to wage-earners, to employers, and to the state, has been longer understood and more persistently neglected.

As a problem in political and social science national health as a factor in national efficiency thus assumes interesting proportions. "Health is wealth," says the proverb, and surely in this country there has been abundant expert testimony as to the importance of national health. The famous Shattuck Sanitary Commission in Massachusetts in 1850 reported the following:

That the average length of human life may be very much extended, and its physical power greatly augmented; that in every year, within this Commonwealth, thousands of lives are lost which might have been saved; that tens of thousands of cases of sickness occur, which might have been prevented; that a vast amount of unnecessary impaired health and physical disability exists among those not actually confined by sickness; that these preventable evils require an enormous expenditure and loss of money, and impose upon the people unnumbered and unmeasurable calamities pecuniary, social, physical, mental, and moral which might be avoided; that means exist, within our reach, for their mitigation or removal; and that measures for prevention will effect infinitely more than remedies for the cure of disease.

We have since had repeated official reminders that within reasonable limits public health is purchasable. And a conservation commission of the Roosevelt administration declared that the aver- 
age span of American life might be increased at least fourteen years if we would but use the knowledge of hygiene already at hand. Economic fact and argument have not been lacking, for our United States Public Health Service has estimated the mere wage loss each year on account of sickness as no less than half a billion dollars. We have had, too, in health matters, the suggestive and helpful background of European experience and accomplishment.

In no more striking way have we benefitted from English experience than in our determination to avoid her blunder of relaxing legal safeguards under war conditions. Great Britain, under prodigious strain to turn out quantities of munitions quickly, continued this mistaken policy until her Health of Munition Workers Committee in a series of reports demonstrated that, even from the standpoint of maximum production, excessive hours did not pay; and that the efficiency of employes had been lowered by overwork.

The committee likewise found that measures to secure good sanitary conditions, lighting, ventilation, and the prevention of accidents and sickness, were also essential to the maintenance of efficiency and output. Fortunately the British reports reached this country before our own entrance into the world war and were used effectively in blocking legislative efforts to break down our own labor laws. Quickly, through organizations that devote themselves to such matters, the warning was given that protective labor regulations are not based upon mere sentiment but upon sound economics. The President of the United States, the Secretaries of the Army and the Navy, the Council of National Defense and public officials generally, finally went on record as opposed to the setting aside of legal standards of protection for men, women and children in our industries. "I think it would be most unfortunate," declared President Wilson, "for any of the states to relax laws by which safeguards have been thrown about labor. I feel that there is no necessity for such action, and that it would lead to a slackening of the energy of the nation rather than to an increase of it."

\section{Financial Aspect}

We have now had opportunity to think and we are not likely to adopt a mistaken policy in reference to maintaining existing protective standards. But it is also our duty, during the war and even because of the war, to take certain steps in advance for the protection of the national health. 
From the human and the social point of view it is necessary that steps be taken beyond the mere provision of sanitary work places. It is essential if we are to attack the problem of health and national effectiveness with vigor and understanding that workmen at the first indication of approaching illness be not held back,either because of commendable dislike of charity or of reluctance to accumulate doctor's bills, - from requesting immediately, as a right, all necessary medical attention. Adequate provision for such service will of course include in addition to all necessary medical care, nursing, medicines and appliances, hospital accommodations and special maternity care. This service should be available not only for the sick employes but also for dependent members of their families. In addition it is essential that cash payments based on a percentage of wages be made to employes when incapacitated by sickness, and that there be in case of death a sum sufficient for decent burial, as is already provided under most of our workmen's compensation laws.

The expense of such thorough-going attention to health will of course be great. But there will also be many important economies. While in the aggregate the estimated totals may appear staggering, it must be remembered that someone is already paying for all the costs of sickness-under present unorganized methods-and the burden is now carried for the most part by those least able to bear it.

But we have learned how huge sums are quickly made available through the accumulation of many small ones. All of the money needed for a comprehensive plan of sickness care can be provided by small weekly payments from both employers and employes under state supervision. And of course on grounds of economy as well as public policy it should be recognized that the plan of insurance against sickness should not be commercial in character.

Hitherto our difficulty in increasing national efficiency through improved national health has not been a lack of appreciation of the possibilities or a lack of knowledge of hygienic precautions. The trouble has been that our leaders in health work could not get sufficient funds. A few years ago an investigator for the Russell Sage Foundation discovered that the average per capita appropriation for public health work by the cities of over 25,000 population was but twenty-two cents a year. In several cities for infant hygiene work, laboratory and dispensary service, housing regulation, industrial 
hygiene, tuberculosis work, control of venereal diseases, health education and publicity, the annual appropriation was less than four cents per person. And this very week in the largest city in this country with a population of more than five millions we have the spectacle of the mayor attempting to abolish the Bureau of Public Health Education on the ground that $\$ 12,000$ for such a purpose is unnecessary. Obviously if we are to tackle the problem of health with "real thinking and sincere action" we must accept methods of financing not yet put in practice here for this purpose although they have long been employed successfully in various countries of Europe.

\section{Health Insurance Problems}

The present premier of England, Lloyd George, impressed by sub-standard conditions of health revealed by selection of soldiers for the Boer War, succeeded in having instituted in 1911 a system of workmen's health insurance as a part of a general social insurance program. Physicians, who seven years ago opposed the plan in Great Britain, are now found by the British Medical Association to be almost unanimously in favor of it. Moreover a delegation of British workingmen who recently toured this country at the request of the American Federation of Labor spoke in terms of highest praise of the health insurance system in England. Germany and other continental countries had learned this lesson still earlier and during the five years preceding the outbreak of the present war six European countries adopted compulsory contributory systems of health insurance.

In the United States the success of workmen's compensation for industrial accidents, which in seven years spread over four-fifths of the country, was followed last year by wise and generous provision by the United States government of accident, health and life insurance for soldiers and sailors. This social insurance legislation has given a new impetus to the health insurance campaign in America where already nine states have provided for official study of the subject through legislative commissions. A number of our most influential state and national labor organizations have gone on record for health insurance legislation, and in New York State the federation of labor this year introduced a bill. It is worth noting that the objection raised to this measure by the secretary of the Associated 
Merchants and Manufacturers of New York State related entirely to the cost. He presented figures indicating that the wage-earners of New York State alone suffer loss of time on account of sickness aggregating 40,500,000 days each year. Necessary care under a health insurance law, he declared, would require the expenditure of $\$ 100,000,000$ more for hospitals alone to equip New York for this service. The funds made available through small weekly contributions by those most directly responsible for sickness and most to be benefitted by improved health would according to this employers' representative be equal to fully forty-six times the amount annually appropriated by New York City for public health work.

The representatives of the wage-earners reply that they welcome this proof of the need for sickness insurance and that they are ready to bear their share of the cost on a fifty-fifty basis with their employers, and they have served notice that they purpose to continue the campaign until proper service is available for every sick employe in the state. They also point out that the objections raised to insurance against sickness were only a few years ago raised against workmen's compensation for accidents, which is now universally admitted to be beneficial to employers as well as to employes. Finally, they suggest the undoubted advantages to industry of the frequent coming together of representatives of workmen and employers in the local mutual administration of the health insurance funds. This they believe will obviate many industrial disputes, and greatly add to the efficiency of the nation's industries. But most urgently they insist that the world of medical science shall be made available to the wage-earners--not merely, as at present, to the wealthy on one hand and through charity dispensaries to the poverty-stricken on the other.

\section{Necessity for a General Sanitary System}

Dr. Hayhurst of the Ohio State Board of Health in his report on The Need for a General System of Sanitary Supervision of Industries in Times of War, states that a general system of sanitation must include four things, one of which is "a system for the prompt care and recovery of those taken sick . . . . and a means of sustenance until well." And he points out that the need of an extension of insurance to cover sickness is particularly needed in connection with our multitude of employes in small establishments. 
"We know," says Hayhurst, "that nothing reduces preventable afflictions more than establishing some form of compensation against them, since this increases inquiry and thus raises the standards for sanitation and hygiene." Surgeon-General Rupert Blue has referred to health insurance as the next great step in social legislation. Dr. Evans, in his presidential address before the American Public Health Association, declared that by the time this war is over health insurance will be the livest issue in America. The official commission which has been studying this question in New Jersey states:

The stress of industry in war is making increasing demands upon physical endurance. In our hour of necessity we have been shocked by the high percentage of draft rejections on account of physical disability. As never before we need now to conserve, for present and future generations, the health and physical vigor of our people. Furthermore, it is the duty of statesmanship to look beyond our immediate pressing needs to the period of reconstruction at the close of the war. We cannot afford to disregard the protective legislative inducements already offered to workmen by our keenest commercial competitors in Europe.

The economic advantage to a nation of a healthy, efficient and contented working class is recognized by employers who have observed the effects of universal insurance against sickness in England and Germany. A former representative of large manufacturing interests, who is now serving in the War Department, wrote to me recently as follows:

I believe very strongly that unless we make very substantial progress along the line of health insurance. . . .we shall find ourselves under very serious handicaps in world competition at the conclusion of the present war. I believe that many of our people are still going cheerfully on with the social ideals and ideas of the past generation quite oblivious to the fact that our great commercial competitors, Germany and Great Britain, have advanced far beyond us in social thinking. The time will come within the years immediately following the war when our "go as you please" methods of industry will be weighed in the balance in competition with Europe.

We are fighting a great world war in order that the condition of the people may be improved. Some time this war will end. But within each nation there is a never-ending struggle for better living conditions, for opportunities for health and happiness that during generations have been denied to the workers. Today, for example, we possess a mighty power to fight disease. To the wealthy class this scientific knowledge is available; to the poverty-stricken it is 
doled out in charity dispensaries. But for the masses of the working population--in the United States alone among great industrial nations-such treatment is not made available.

The healthiest army in history is what our officers and sanitarians at the front are striving to make of the American forces abroad. Why should not the same ideal be set up for the much more numerous army of industrial workers at home, without whose unhampered productivity the valor of our troops will be useless? In health legislation the war has not furnished a ground for postponement of action; rather it has increased the need for action. And in fulfilling this immediate and urgent duty to aid in the successful prosecution of the war we shall at the same time be laying a firm basis for reconstruction after the war.

President Wilson in his remarkable letter to New Jersey politicians, quoted at the beginning of this paper, also said:

Every sign of these terrible days of war and revolutionary change, when economic and social forces are being released upon the world whose effect no political seer dare venture to conjecture, bids us search our hearts through and through and make them ready for the birth of a new day-a day, we hope and believe, of greater opportunity and greater prosperity for the average mass of struggling men and women, and of greater safety and opportunity for children. . . . .

[In] the days of political and economic reconstruction which are ahead of us, . . . . every program must be shot through and through with utter disinterestedness; . . . . every party must try to serve humanity; . . . . overy program, every measure in every program, must be tested by this question, and this question only: Is it just; is it for the benefit of the average man, without influence or privilege; does it embody in real fact the highest conception of social justice and of right dealing without respect of person or class or particular interest?

This is a high test. It can be met only by those who have genuine sympathy with the mass of men and real insight into their needs and opportunities, and a purpose which is purged alike of selfish and of partisan intention.

The party which rises to this test will receive the support of the people boจgnвo it serves it.

While we make ready for the birth of a new day, in what our President has called this "exigency of a great hour of crisis," we will do well to remember that the workmen when they return from the trenches will demand sincere action, and that it is well for our national health and national efficiency that "they will not be satisfied with flowers or brass bands." 